\title{
Coronaglobal v angloamerickém světě
}

\author{
Oleg Suša \\ Filosofický ústav Akademie věd ČR, CZ
}

SUŠA, O.: Coronaglobal in the Angloamerican World
Philosophica Critica, vol. 6, 2020, no. 1, ISSN 1339-8970, pp. 118-126

In this article I focus on several dimensions of the pandemic in the Angloamerican world. In the first part I try to make a survey analysis of the Covid 19 epidemic burst in the USA and the United Kingdom, focusing on the specific traits in societal governance and reactions in society in figures. Second part is exploring some important aspects of coronaglobal crisis from the point of view of critical social explanation of the global risk society, risk definition and power. Modern institutions and their global interactions are unable to control effectively uncertainty and ambivalence which they are co-producing. Living in the global risk society creates rising uncertainty and vulnerability of powerless individuals who are disposed from the capacity to risk definition. In the third part I focus on the pandemic infection as a part of the global environmental crisis. Human health is a boundary sphere between humans and ecosystems. It is related to processes resulting from exploitation linked to privatisation, commodification, and weaponization.

Key words: Globalization - Pandemia - World risk society Coronaglobal - USA - United Kingdom - Organised irresponsibility

Rok s magickým číslem 2020 začal novou pandemií. Žijeme v době environmentálních katastrof, $\mathrm{v}$ době intenzivních transnacionálních a lokálních interakcí, obchodu, mezikontinentálních výrobních a spotřebních sítí, masového turismu a obecné mobility lidí. Mluvíme proto o kompresi času a prostoru. A právě díky této nebývalé mobilitě se šiří nový koronavirus. Kvưli nové globální pandemii dochází k náhlému minimalizování mobility a otevřenosti, státy postupně omezují pohyb osob jako ve výjimečném stavu. Podobně jako ve válkách musejí lidé omezit vycházení a trávit celé dny v sociální izolaci. Nemohou vyrážet do obchodních středisek, nemohou cestovat, nemohou do kaváren a restaurací a hospod, nemohou na stadiony a na sportovní závody, do kadeřnických salonů atd. Pro mnoho 
lidí zvyklých denně konzumovat se to zdá být strašlivým omezením jejich svobody.

Právě USA si toto omezení patrně nebyly schopny připustit, karanténní omezení se prosadila patrně se zpožděním. Navíc působí komplexita federálního uspořádání organizace a správy a rovněž velká a rozmanitá populace s tř́íní a rasovou stratifikací, s velkými sociálními rozdíly a sociální nerovností. V současnosti je v USA skoro milion a čtvrt nakažených virem (1 237 633) a přes 70 tisíc osob na nákazu zemřelo (72 271). Nejvíce pandemie působí ve státě New York se 330139 nakaženými a 25204 mrtvými. (Worldometer: 5. 5. 2020). Rovněž ve Velké Británii došlo k velkému epidemickému růstu, zejména po 16. březnu, do dnešního dne je tam celkem 194990 nakažených a 29427 zemřelých. V Kanadě je to 62046 nakažených ku 4043 zemřelým. Na Novém Zélandě je to 1486 nakažených a 20 zemřelých. (Worldometer: 5. 5. 2020).

Bylo to způsobeno nejspíše př́lišnou sklerózou veřejné sféry, slabými zdroji ve veřejné zdravotní infrastruktuře spolu se souvisejícím dlouhodobým oslabením podpory veřejných potřeb a politikou škrtů státu ve jménu vyrovnaného rozpočtu. Patrně působila subjektivně rovněž hédonistická laxnost mnoha obyvatel, kteři se nechtěli disciplinovaně omezit. Liberální etická norma „Já především“ takto mnohé vychovávala na základě doktríny o tom, že neexistuje něco jako společnost, existují jen jedinci. Atomizovaní jedinci pozdního postindustrialismu se stále víc prekarizovanou existencí, často ovládaní dluhem, se obtížně orientují ve světě a podléhají mediální manipulaci. V americké společnosti existuje mnoho jedinců, kterým není blízká disciplinovaná poslušnost k nařízením vlády.

Obecně je možno konstatovat, že se projevila notorická praxe kapitalismu, v níž problémy celé společnosti vyprodukované vyráběnými riziky má vyřešit stát - ovšem jen za podmínky, že bude zachován růstový motor a zisky soukromého byznysu. Byznys často vydělává na managementu rizika i na katastrofách (tzv. disaster capitalism). V těchto podmínkách nelze snadno zmobilizovat masu jedinců $\mathrm{k}$ nebývalé disciplíně a solidaritě ohledů, kterou katastrofa epidemie celospolečensky vyžaduje. Disfunkce společnosti a absence sociální solidarity se kvůli individualizaci a nízké sociální kohezi projevují v důsledku rychlé polarizace sociálních nerovností soudobého globálního kapitalismu.

V konkrétních podmínkách a situačních kontextech je možno zkoumat selhání institucí, osob v rozhodovacích pozicích či selhání (kapitálem zneschopnělého) státu jako systému. Roli hrají metody austeritního vládnutí spojené s neoliberální vírou v malý a laciný stát. Díky politice dlouhodobých škrtů veřejných výdajů došlo k oslabení národního zdraví a celospolečenské zdravotní ochrany a bezpečnosti. V USA nemá dvacet sedm a půl 
milionu lidí žádné zdravotní pojištění. Všeobecná zdravotní péče je zajištována infrastrukturou veřejného zdravotnictví, na němž závisejí i bohatí. Množství služeb a výkonů je privatizováno, takže i pojištěné osoby se bojí být nemocní, často otálejí s návštěvou zdravotního zařízení a čekají, až se stav zhorší.

V New Yorku nedávno došlo ke zrušení dvaceti tisíc nemocničních lůžek kvůli škrtům ve veřejné sféře. Neoliberální „small government“ způsobil prodlení, v němž mezitím rychle došlo k nakažení lidí v komunitách, ačkoli jak americké, tak britské vládnoucí špičky bagatelizovaly koronavirus jako svého druhu jenom chřipku. Prezident USA omezil přístup k základní zdravotní péči pro imigranty žádající o povolení k pobytu s tím, že mají být soběstační. Také afroamerické komunity nemají snadný přístup ke zdravotní péči, navíc v jejich komunitách je tradiční nedůvěra ke zdravotnictví.

Trumpova administrativa se snažila od počátku krize dopad zlehčovat v obavách o zajištění důvěry investorů (kapitálu) a také kvůli znovuzvolení Trumpa prezidentem pro druhé období. Podobně i v Británii v čele s konzervativní vládou Borise Johnsona docházelo k bagatelizaci problému a pandemie byla ve stínu brexitu.

Kromě toho pronikají zprávy o tom, že CIA i další zpravodajské služby tajně varovaly před pandemií, koronavirus byl nazván „čínským“ a „cizím“. Britský premiér zas hovořil o „stádní imunitě“, v níž má být populace vystavena infekci najednou, aby se jí zbavila. Promoření populace náhle a masově navozuje obraz středověké morové rány a sociální darwinismus přežití silnějšího.

V USA na pandemii reaguje stát fiskálně, ekonomicky i direktivně. Federální rezervní systém 3. března přistoupil k sérii snižování úrokových sazeb a začal nakupovat zpětně cenné papíry. Dne 6. března zahájil prezident sociálně-ekonomickou výpomoc a podepsal příděl 8,3 miliardy dolarů na vývoj léku proti koronaviru a na boj s pandemií. Kritici viní tuto politiku ze slepoty ke globalitě pandemie a vzájemné propojenosti světa, kde nelze pandemii léčit doma a pokračovat v politice sankcí a agresí v ostatním světě. Trump dokonce obhajoval zabavení ochranných pomůcek ve prospěch amerického státu mimo jeho území. Heslo „America first!“ se naplnilo v pirátském hávu. Dne 13. 3. demokraty ovládaná Sněmovna reprezentantů schválila zákon o zavedení bezplatného testování, dotace Medicaid programu a zvýšení podpor v nezaměstnanosti. Prezident vyhlásil mimořádný stav a rozdělil 50 miliard dolarů jednotlivým státům a oblastem. Senát ovládaný republikány dne 18. 3. schválil návrh Sněmovny a druhý den navrhl nový balíček. Začal spor o další kroky. 23. března byl schválen zákon s částkou 2,2 bilionu dolarů, v jejímž rámci je 250 miliard dolarů vyčleněno na př́mé platby jedincům a rodinám s nejnižšími 
př́ijmy. 350 miliard dolarů je na půjčky pro malé podniky, 25 miliard dolarů na dávky pojištění v nezaměstnanosti a 500 miliard dolarů na půjčky firmám v nouzi. 0 pomoc v nezaměstnanosti požádalo víc než 7 milionů lidí - zatím.

Zmiňme ještě otázky o bumerangových efektech. Je možno chápat koronavirovou krizi jako varování před důsledky devastace planety Země a souvisí to $\mathrm{s}$ klimatickou krizí a s dogmatem lidského panského postoje ke zvířatům a rostlinám? Může donekonečna pokračovat koexistence lidského pravěkého pojídání divokých zviŕrat, industriální produkce masa a ekologická krize zrychleného vymírání živočišných druhư? Selhala demokratická kontrola militarizace vědecko-technického rozvoje, zejména aplikace biomedicínského a genetického inženýrství, ale též farmaceutického průmyslu, jejichž produkty jsou také epidemické virové mutace? Je krize velký experiment na lidstvu, je to případ nezamýšlených vedlejších důsledků „slepého“ pokroku technovědy v zájmu vydělávání velkých zisků? A tak bychom mohli pokračovat v kladení otázek, na něž hledat odpovědi opravdu není lehké.

Je jisté, že v blízké budoucnosti obrovsky naroste jistota našich nejistot, každodenně si lidé uvědomí, že žijeme v rizikové společnosti, která má globální rozměry. Nikdo dnes neví, jak dlouho se budou ve světě ničivě projevovat virové epidemie. Již nyní vidíme sílící očekávání masy obyvatel, že instituce budou plnit funkce ochrany jistot přežití. Bezpečnostní ohrožení zesiluje potřebu (znovu) budovat stát. To se již projevuje v podobě finančních injekcí do ekonomik, $v$ plánech na převzetí oborů a odvětví do znárodněného rámce, ve snahách o větší investování do veřejných potřeb a do udržení lidské společnosti v relativně funkční podobě. V demokratickém ustavení je ideálem budování státu zdola společnou iniciativou spoluobčanů. Jestliže se k bezpečnostním ohrožením započítá pandemie, ekonomický úpadek většiny zemí, hrozby válek a ekologická devastace, pak racionální reakcí by mělo být rychlé a účinné semknutí se a spolupráce všech v novém budování celosvětového globálního vládnutí, nikoli vojenské konfrontace a boj o nadvládu a o nedostatkové zdroje. Již dnes se potvrzuje poznání, že lidský svět vyžaduje zásadní změny. Zda budou znamenat zlepšení a nový start či rozkvět, nebo naopak úpadek, to bude záviset na nás i na budoucích generacích.

\section{Globální riziková společnost, definice rizik a moc}

Současná globalizace přinesla množství nejistot, jež působí svými důsledky v rámci světové rizikové společnosti (Beck 2005) i v rámci lokálních společensko-ekologických kontextů. Ulrich Beck ukázal, že rizika jsou 
dnes nevypočitatelná, neviditelná a obtížně pojistitelná. Globální interakce moderních společenských institucí přinášejí nejednoznačnost důsledků pro člověka.

Život v rizikové společnosti znamená jistotu nejistot a ambivalentní charakter těchto důsledků: kupříkladu věda hledá řešení problémů pomocí jejich poznání, avšak zároveň se podílí na konstruování a vytváření nových rizik. Věda je zapojena do technicko-industriální aparatury, která proměňuje svět, a je tak částí globální metamorfózy komplexních a planetárních rozměrů, v níž společnosti ohrožují sebe sama i životní prostředí a ekosystémy na celé planetě.

Pandemie typu COVID-19 jsou částí, aspektem tohoto komplexu globální metamorfózy, která získává neřízenou povahu. ${ }^{1}$ Globální transfery fyzikálních, chemických a biologických látek, znečištění či mobilita osob také zrychlují pandemické katastrofy. Vlády všech států včetně supervelmocí jako USA vesměs nepředvídaly a nereagovaly včas na globální pandemii. Instituce byly překvapeny rychlostí pandemie.

Dủležitým momentem je skutečnost, na kterou poukázal U. Beck: je to popírání existence světové rizikové společnosti, jež paradoxně uspíší její uskutečnění - ignorování globalizace rizik urychluje jejich globalizaci (Beck 2006, 330). Mocenské špičky vlád USA a Británie bagatelizovaly nebezpečí koronaviru, WHO váhala s vyhlášením globální pandemie, Čína utajovala počátky epidemie, Evropská komise podcenila globalitu pandemie. Ironií rizik nazval Beck to, že často kalkulujeme budoucí rizika podle minulých, ale nevidíme nová nebezpečí, s nimiž nepočítáme. Příkladem je jednání armád a strategické zbrojení, jež se připravují na válku v intencích minulé zkušenosti. Podobně to vypadá s reakcemi dalších byrokratických institucí bez ohledu na proklamovanou flexibilitu a efektivnost, které tak dlouho propagovala neoliberální ideologie globálního nového světového řádu.

Podle Becka je život v globální rizikové společnosti způsobem existence lidstva v 21. století. Radikalizace nejistot a „výroba nejistot“ (Giddens 1990) znamená nedostatek bezpečí jak v ekonomickém, tak v sociálním, environmentálním i zdravotním ohledu. To kontrastuje s moderní vírou v př́slib jistoty a bezpečí, kterou mají zajistit instituce moderní společnosti. Radikalizovaná nejistota je situací, jež konfrontuje instituce vědy, státu, byznysu s poznáním, že nejsou jen nástroji řízení a kontroly rizik „expertními systémy“, na kterých se moderní lidé stali závislými (Giddens 1998), ale jsou jejich zdrojem. Soudobý medicínský a biomedicínský

Na Beckovu poslední knihu o Metamorfóze světa odkazuje nyní J. Habermas a M. Hrubec to reflektuje ve svém prvním článku tohoto tematického čísla časopisu. 
genový a farmaceutický průmysl je relevantním příkladem ambivalence rizik a výroby nejistot $v$ situaci nynější katastrofy pandemického šíření nákazy nemoci COVID-19, kdy o ní stále víme jen velice málo.

V každodenním životě rizikové společnosti se utváří nová individualizace, v globalizovaném světě se lidé musejí vyrovnávat s nejistotou a selháváním institucí i expertních systémů; jsou odcizeni od těchto institucí a systémů, nemají však za ně náhradu. Anthony Giddens ukázal na centrální důležitost udržení „důvěry v abstraktní systémy“. Ulrich Beck zas zdůraznil společenské konflikty spojené se snahami institucí cynicky svádět odpovědnost za své selhání na jedince.

Beck ukázal konflikt mezi postoji k riziku. Jedním je předpoklad, že něco je bezpečné, dokud se neprokáže, že je to nebezpečné. Druhým postojem je předpoklad předběžné opatrnosti, že nic není bezpečné, dokud se neprokáže, že to není škodlivé (Beck 2006, 336-337). Průběh pandemie v USA i v Británii ukázal převládání prvního postoje, který se ukázal jako hazardní v situaci limitů tamní dostupnosti masové zdravotní péče. Bilance v USA s nejvyšším počtem mrtvých na koronavirus na světě, s nejhorší situací v New Yorku, je smutným dokladem problematičnosti důvěry v systém a jeho efektivnost $\mathrm{v}$ uspokojování veřejných potřeb - zejména veřejného zdraví a zaměstnanosti.

Kandidát Demokratické strany Joe Biden požaduje, aby vláda Spojených států investovala do dlouhodobých cílů zaměstnanosti, infrastruktury a ochrany klimatu a kritizuje vládu Donalda Trumpa za nekontrolované utrácení peněz. Trump zas požaduje navýšení financí pro nízkoúročné půjčky firmám s méně než pěti sty zaměstnanci. Oběma jde o podzimní volby prezidentské.

Globální spolupráce je omezená, krize ukazují, že národní státy nesly hlavní břemeno boje s pandemií. USA obvinily Světovou zdravotnickou organizaci a Čínu, že téměř zavinily globální rozšíření koronaviru, ale byly to právě Spojené státy, které již nejméně pět let spolupracovaly s Čínou na laboratorních pokusech a financovaly výzkum netopýŕího koronaviru v laboratoři ve Wuchanu. ${ }^{2}$ Technologické hazardy jsou systémové, jejich takzvané nehody nejsou náhodné, jak ukázaly případové studie Ch. Perrowa (Perrow 1978). Moderní společnosti žijí s vysoce rizikovými technologiemi a byrokratické instituce, které se tváří, že riziko kontrolují, praktikují „organizovanou neodpovědnost“ - domnívají se Perrow i Beck. Velmi se to týká průmyslu, armády, energetiky.

2 Nynější pandemie je svými důsledky v různých lokalitách podobná nevyhlášené válce $s$ nejasně definovaným neprrítelem jménem „COVID-19“ (což připomíná vojenské názvy zbraní). Moderní technologie produkují zároveň „jedy i protijedy“ a instituce praktikují „organizovanou neodpovědnost“ (Beck 1988). 


\section{Od krize ke katastrofám}

Od počátku diskusí o ekologické krizi bylo lidstvo varováno před katastrofami, které hrozí, pokud nedojde k systémové transformaci industriálně-kapitalistického modelu civilizace. Místo toho se tento model globalizoval a rozšířil na celý svět. Každý soudný člověk dnes může vidět a svými smysly zakoušet dopady rozvoje globálního kapitalismu v podobě globálních nerovností mezi bohatnutím a chudnutím i v podobě ekologických katastrof (Suša 2019; Hrubec 2019a). Jsou hmatatelným důkazem, že systém, jenž nás všechny ovládá, zašel až příliš daleko v destrukci životního prostředí a přírodních i sociálních ekosystémů (Suša - St’ahel 2016). S tím je spojen rozvrat biodiverzity a komodifikace života i zdraví. Lidské zdraví tvoří mezní systém mezi lidmi a ekosystémy, člověk nestojí nad př́rodou, ale je její součástí, je na ní závislý. Je to etický a zároveň biologický fenomén. Globální zdravotní krize má souvislost s ekologickou krizí, jak to připomíná řada autorů ve světě i u nás, mezi jinými Vlastimil Hála. Ten konstatuje, že pandemie souvisí s otázkami ekologické krize a se zásahy člověka do prrírody, kdy společným jmenovatelem je chování člověka vůči př́rodě.

Mezi mnoha varováními před katastrofami lze zmínit např́́klad V. Smila, který predikoval řadu pandemií mezi lety 1996 - 2020 (Smil 2008). Před celou řadou katastrof, jež mají vyvrcholit globálním oteplením, varoval také Ch. Perrow (Perrow 2011). Požáry, sucha, záplavy, odlesňování, znečištění ovzduší, půdy a vody, hazardní produkce a spotřeba-drancování zdrojů planety s pokračujícím těžením renty také v privatizacích zdravotní péče - to jsou některé z významných rysů komplexu procesů v přechodu od krize ke katastrofám. Současná koronavirová krize není př́ležitostí, ale lidskou katastrofou a reakce na ni zakládá další lidskou katastrofu (Laurent 2020).

Velikost lidské katastrofy dokládá statistika obětí koronaviru - v USA přes sedmdesát tisíc mrtvých a ve Velké Británii přes dvacet devět tisíc mrtvých. Spojené státy byly rozsahem lidské katastrofy a kolabujícího zdravotnického systému přirovnány k rozvojové zemi (Stiglitz 2020).

Marnost varování a ignorance mocných podporujících snahy kapitálu o nepřerušený růst růstu, devastací pro zisk je ilustrována také dekretem prezidenta Trumpa o „americké obnově a využití vesmíru“. Vesmír je oblastí aktivity lidí, a nikoli globální veřejný statek. Proto je třeba komerčně rozvíjet vesmír a těžit zde suroviny. ${ }^{3}$ Expanzivní plány kapitálu neodradí

Dekret potvrdil rozhodnutí amerického Kongresu z roku 1915, jenž dal Američanům právo na komerční průzkum, těžbu a využití zdrojů ve vesmíru. Spojené státy budou chránit korporace využívající zdroje. 
zřejmě ani lidské tragédie a bumerangové efekty průmyslových a vojenských pokusů.

Spojené státy mají v koronavirové katastrofě víc mrtvých než padlých vojáků ve vietnamské válce, přesto ale pokračují v závodech ve zbrojení, na sociální a zdravotní péči šetří, ale ve výdajích na válku jsou globálním lídrem. V roce 2019 měly USA podíl 38 \% na globálních výdajích na zbrojení, na druhém a třetím místě jsou Čína a Indie. Za poslední dekádu došlo k dalšímu globálnímu nárůstu zbrojních výdajů (SIPRI 2020). Zbraně nakupují státy a jejich armády za prostředky daňových poplatníků. Tyto finanční prostředky pak chybí v sociální a zdravotní oblasti. Zbrojení je legitimizováno budováním bezpečnosti jednotlivých států, vojenských paktů a aliancí, přitom napomáhá větší nejistotě v mezinárodních vztazích a stupňuje nebezpečí války (Hrubec 2019b).

Namísto slova „válka“ se dnes používají pojmy jako bezpečnostní rizika nebo konfliktní napětí, namísto rozvoje podmínek pro emancipovaný rozvoj člověka se připravují barbarské akty konstrukce vysoce účinných zbraní hromadného ničení včetně zbraní biologických, chemických a kosmických v zájmu vojensko-průmyslového komplexu a pružně vznikajících aliancí kapitálu. Na těchto aktivitách participuje také finanční kapitál a jeho finanční produkty investic do kosmického dobývání nebo těžby nafty a dalších surovin v oceánu a v Arktidě, ale také do katastrof. Globální příčiny i důsledky těchto katastrof a jejich lokální dopady vyžadují naléhavě a rozhodně globální spolupráci, která je bohužel zatím oslabena a je nedostatečná. Zároveň pandemie zatím způsobila určitou lokalizaci řešení komplexu problémů s růstem významu státu. Pandemie ukazuje větší spoléhání na státy, ale i frustrace z jejich selhání. Nicméně výhledové katastrofy klimatické změny a ekologicko-politicko-ekonomicko-sociálních krizí nelze zvládnout lokálně, bez globální spolupráce.

\section{Literatura:}

BECK, U. (2005): Riziková společnost. Praha: Sociologické nakladatelství.

BECK, U. (2006): Living in the world risk society. In: Economy and Society, 35 (3), $329-345$.

HARVEY, D. (2015): Seventeen Contradictions and the End of Capitalism. London: Profile Books.

HRUBEC, M. (2019a): Social and environmental conflicts or sustainable development? In: Civitas, 2 (19), 281 - 295.

HRUBEC, M. (2019b): Threat of limited nuclear war. In: Critical Sociology, 45 (6), $785-798$.

GIDDENS, A. (1998): Důsledky modernity. Praha: Sociologické nakladatelství. 
LAURENT, E. (2020): The four worlds of the social-ecological state. 30. 4. 2020. Web. 30. 4. 2020. <www.socialeurope.eu/the-four-worlds-of-the-socialecological-state>.

PERROW, C. (1999): Normal Accidents: Living with High Risk Technologies. Princeton: Princeton University Press.

PERROW, C. (2011): The Next Catastrophe: Reducing Our Vulnerability to Natural, Industrial and Terrorist Disasters. Princeton: Princeton University Press.

SMIL, V. (2008): Global Catastrophes and Trends: the Next Fifty Years. Cambridge: MIT Press. České vydání (2017): Globální katastrofy a trendy: přištích padesát let. Zlín: Kniha Zlín.

STIGLITZ, J. (2020): US Coronavirus response is like "third world" country. 22. 4. 2020. Web. 30. 4. 2020. <www.theguardian.com./business/2020/ apr/22/top-economist-us-coronavirus-response-like-third-world-country-joseph-stiglitz-donald-trump >.

SUŠA, O. (2019): Global risks and conflicts: the social, environmental, and political consequences. In: Critical Sociology, 45 (6), 829 - 843.

SUŠA, O. - Stáahel, R. (2016): Environmetální devastace a sociální destrukce. Praha: Filosofia.

SIPRI (2020): Global military expenditure sees largest annual increase in a decade. 27. 4. 2020. Web. 30. 4. 2020. <www.sipri.org/press-release/2020/globalmilitary-expenditure-sees-largest-annual-increase-in-a-decade>.

PhDr. Oleg Suša, CSc.

Centrum globálních studií

Filosofický ústav AV ČR

Jilská 1,11000 Praha 1

susa@flu.cas.cz 